\title{
An Assessment of Zakat Contributions for Productive Purposes to Empower the Mustahik Economy in the Face of the Covid-19 Pandemic
}

\author{
Raisa Aribatul Hamidah ${ }^{1 *}$, Azhar Alam ${ }^{2}$, Arum Anggraeni ${ }^{3}$, and Renaldi Sahrul \\ Nizam $^{4}$ \\ ${ }^{1}$ Faculty of Economics, Universitas Islam Batik Surakarta \\ ${ }^{2,3,4}$ Faculty of Islamic Studies, Universitas Muhammadiyah Surakarta, Indonesia
}

\begin{abstract}
People have lost their jobs as a result of the COVID-19 pandemic, and many people are now living in poverty. Zakat is one of the Islamic pillars concerned with poverty reduction, particularly in the form of productive disbursement. The purpose of this research is to identify and assess the mechanisms and contributions of productive zakat to economic empowerment mustahik during the COVID-19 pandemics. Zakat for productive purposes is wealth that enables the recipient to continuously create creativity using zakat funds. This study conducted in-depth interviews with three Zakat institution staff and seven Mustahik who live in a low-income society and are economically impacted by COVID-19. This study used the descriptive method, with data retrieval in this study using the interview method, followed by data analysis in the form of data reduction, data presentation, and conclusions. According to the findings of this study, there is still a limited number of human resources available for mustahik coaching and supervision at LAZISMU Pemalang. This paper discovered that not all mustahiks use 100 percent of productive zakat funds to develop their businesses as hoped, but instead meet basic needs. Mustahik primarily requires more fulfillment with short-term benefits in order to sustain their lives.
\end{abstract}

Keywords: Evaluation; Productive Zakat; Mustahik Economy; LAZISMU; Covid19

*Corresponding author: raisaribatu19@ gmail.com

Received: July 05, 2021; Accepted: December 23, 2021; Published: December 25, 2021 

Abstrak: Pandemi Covid-19 telah menyebabkan banyak orang kehilangan pendapatan dan hidup dalam kemiskinan. Zakat merupakan salah satu rukun Islam yang concern terhadap pengentasan kemiskinan terutama dalam bentuk penyaluran produktif. Penelitian ini bertujuan untuk mengetahui dan mengevaluasi mekanisme dan kontribusi zakat produktif terhadap pemberdayaan ekonomi mustahik selama masa pandemi covid-19. Zakat untuk tujuan produktif adalah kekayaan yang memungkinkan penerimanya untuk terus menerus berkreasi yang bersumber dari dana zakat yang diperoleh. Penelitian ini dilakukan dengan wawancara mendalam yang melibatkan tiga staf lembaga zakat dan tujuh orang mustahik yang memiliki masyarakat berpenghasilan rendah dan terkena dampak ekonomi dari covid-19. Penelitian ini menggunakan metode deskriptif, dimana pengambilan data dalam penelitian ini menggunakan metode wawancara, kemudian dilakukan analisis data berupa reduksi data, penyajian data, dan penarikan kesimpulan. Penelitian ini menemukan bahwa masih terbatasnya Sumber Daya Manusia yang melakukan pembinaan dan pengawasan yang dilakukan oleh LAZISMU Pemalang terhadap mustahik. Tulisan ini mengungkapkan bahwa tidak semua mustahik menggunakan $100 \%$ dari dana zakat produktif untuk mengembangkan usaha seperti yang diharapkan, tetapi mereka memenuhi kebutuhan sehari-hari. Mustahik memprioritaskan banyak pemenuhan kebutuhan yang memiliki manfaat jangka pendek untuk mempertahankan hidup mereka.

Kata kunci: Evaluasi; Zakat Produktif; Ekonomi Mustahik; LAZISMU; Covid-19

\section{INTRODUCTION}

Coronavirus disease is still a hot topic in many parts of the world. As of October 2, there were 34,494,967 confirmed cases of covid-19 worldwide, with 1,027,777 deaths and 25,677,764 confirmed cures. (Worldometer, 2020). Covid-19 is one of the new types of viruses that emerged from traditional markets in Wuhan, China, beginning with a traditional market that sells animals, including wild animals, and affecting hundreds of countries. One such effect has been felt by the global economy. The global economy's percentage growth rate is expected to fall by $2 \%$. (IMF, 2020)

China, which was the first country to confirm the presence of covid-19 at the end of 2019, also experienced economic shocks in agriculture and export-import trade. (Zhang et al., 2020). China has implemented all policies, including lockdown, to reduce the spread of Covid-19. A country's economic growth is impacted by a lockdown. Other countries affected by the Covid-19, such as Indonesia, use it as well.

In March, Indonesia reported the first case of Covid-19. Until now, the number of confirmed positive covid-19 cases in Indonesia has nearly reached 300,000 people. According to the most recent Covid-19 Task Force data, there are 307,120 positive cases until October 2020. (Satuan Tugas Penangan COVID-19, 2020). As a result of the pandemic, there have been numerous attacks on society's economic sector. They're starting with the Indonesian government's March policy, which called for the implementation of lockdown and Pembatasan Sosial Berskala Besar (PSBB), or Large-Scale Social Mobility Restrictions. 
The pandemic policy has an impact on all groups, from the upper to the lower classes. One of the visible effects is in the field of employment. Many employees are let go from their jobs. Because the demand for a product has decreased, the company does not have to pay its salary and instead decides to repay it. The Ministry of Manpower has identified 1,943,916 employees who have been affected by the covid-19 pandemic (Kurniawansyah et al., 2020).

The country of Indonesia is still unable to solve the problem of poverty, which has steadily increased from year to year. Poverty rates skyrocketed as a result of the pandemic. This situation has arisen as a result of policies that have resulted in the dismissal of employees and businesses. According to BPS data released in July 2020, the poverty rate in March 2020 was 9.78 percent (Central Bureau of Statistics, 2020). The figure has risen by 0.56 percent since September 2019. With a total population of 26.42 million poor people spread across Indonesia's urban and rural areas. With the poverty rate continuing to rise during this pandemic, a device to alleviate poverty and assist people infected with COVID-19 is required.

Indonesia is a Muslim-majority country. Islam regulates the value placed on mutual assistance. The upper class must raise awareness in order to assist the lower classes during the pandemic. Zakat distribution is one of the possible actions. Zakat is one method of distributing aid to those who are eligible, particularly those living in pandemic-affected communities. One of zakat's objectives is to increase economic empowerment. Indonesia is predominantly Muslim. Islam regulates the value placed on mutual assistance. With the pandemic, the upper class must educate the public in order to assist the lower class. Zakat distribution is one of the possible actions. Zakat is a method of distributing aid to those who are eligible, most notably those afflicted by a pandemic. One of zakat's goals is to increase economic empowerment (Faisal and Yuliani, 2018). Furthermore, in a pandemic like this, zakat should be distributed earlier to the affected parties in order to help the economy of the zakat recipients (mustahik), as arranged by the Ministry of Religion by issuing Letter No. 8 in the year 2020. (Fauziyah, 2020).

Zakat makes a significant contribution to the mustahik's economy. When zakat is distributed to those who are entitled to it or in need of it, it invariably creates employment. Mustahik's life will improve as the number of jobs increases. Not only mustahik benefit, but so do other communities. Other communities' needs are met as a result of the needs of Mustahik. More jobs are expected to boost the country's economy, reducing unemployment and poverty rates caused by the pandemic.

Zakat is not only something that can be used up (consumptive), but it can also be something that is continuous and will not be exhausted (productive). Because of the existence of Productive zakat, people who face business constraints as a result of the pandemic after receiving Productive zakat can still run a business and meet their own needs. That is, they are no longer reliant on third parties to meet their needs. (Fitri, 2017). Zakat will have an impact on all aspects of life. 
Zakat can be used to build kinship between muzakki and mustahik parties. Zakat can also help with economic empowerment. With the distribution of productive zakat, it is hoped that the community's expertise in running a business will grow. (Fajrina et al., 2020). Small and medium-sized businesses are expected to contribute to increased domestic production as a result of the establishment of these businesses. As a result, Indonesia's economy will soon recover following the pandemic.

Productive zakat can be distributed in the form of money to be used for business purposes. Furthermore, it can be given directly in the form of goods that can be used as capital to start a business. The funds allocated to Mustahik are not used solely for consumption, but are also used as fixed capital. Later zakat funds obtained are expected to contribute to helping businesses that have been scheduled and provide business income in a specific time that can gradually and sustainably become a permanent source of income for mustahik. When the condition is running, wide open position mustahik unto raising the class to muzakki. (Widiastuti \& Rosyidi, 2015).

All results obtained from the contribution of productive zakat will run smoothly if they are managed properly. As a result, in order to facilitate the distribution of zakat, an institution that manages it is required. It has been stipulated in law No-23 of 2011 with an existing legal umbrella that protects and strengthens zakat management, after which good zakat institutions from the government and the formation of society appeared (Leli, 2020). Lembaga Amil Zakat Infaq Sadaqah Muhammadiyah (LAZISMU) is one of the community's institutions formed to collect, manage, and distribute zakat. The recipients are those in need, particularly Mustahik, which has a low economy and is now affected by Covid-19 (Dewan Syariah Lazis Muhammadiyah, 2011).

Amil zakat institutions can make a significant contribution to the economy mustahik in order to create justice for the poor. The number of research papers on zakat productive and linked to pandemic Covid-19 is still limited. This study was the first to contribute to the discovery of a productive zakat implementation in the midst of the Covid-19 pandemic. Based on the problem's introduction, the purpose of this paper was to describe and evaluate the contribution of productive zakat to the economic empowerment of mustahik during the Covid-19 pandemic, using LAZISMU Pemalang as a case study.

\section{RESEARCH METHODS}

Descriptive methods were used in this study. The descriptive method is one that demonstrates what the object and subject being studied are. Researchers have no trouble coming up with problems to solve in order to collect the necessary data in the field (Hermawan 2019). 
To obtain detailed information, researchers use an interview method of data collection. When conducting interviews, one must select a source who is knowledgeable about the subject matter and can be trusted to tell the truth. (Sugiyono 2013). As a result, the researchers conducted interviews with ten respondents, including LAZISMU Pemalang employees.

In this study, ten respondents were interviewed in depth, including three LAZISMU Pemalang staff members and seven mustahiks. The author then performs the stage of data analysis on the data obtained from some of the above methods to facilitate the processing of information obtained from the source. Some of the stages of data analysis used by the author include data reduction, which is the process of summarizing data obtained from research and eliminating data that does not fit the theme chosen. Then, data presentation is the process of presenting summarized data that is then organized in a structured manner to aid in data comprehension. Finally, drawing conclusions is the process of summarizing the entire data from multiple data analyses in order to determine the results of a study.

\section{RESULTS AND DISCUSSION \\ Mechanism of Allocating Productive Zakat to Mustahik During the Covid-19 Pandemic}

According to interviews with LAZISMU Pemalang staff, efforts are being made to improve the well-being of underprivileged communities through economic empowerment programs.

LAZISMU Pemalang received a letter from the central leadership to run a program to distribute funds for businesses affected by covid-19, namely through the productive zakat program, at the start of the development of covid-19 inIndonesia.

Productive zakat is a type of distribution that uses capital or funds to keep the economy running and has long-term benefits. Productive zakat has long-term benefits if the fund's business is managed as well as possible by mustahik. The implementation of productive zakat has been carried out since the time of the Prophet (peace be upon him), when he was charitable to the fakir in order to meet basic needs and purchase goods that could be used for work, allowing the fakir's needs to be met (Rianto et al., 2016).

LAZISMU Pemalang implemented the effective zakat program distributed in the form of small business capital for the first time in September 2020 by granting funds to 27 mustahik who were selected and had capital constraints after the pandemic. As a result, one of the work programs that the author will investigate is a successful zakat program during the Covid-19 pandemic. The covid-19 virus first appeared in Indonesia in early March 2020, wreaking havoc on many health and economic sectors. Leaving the problem aside, LAZISMU Pemalang strives to empower the mustahik economy during the pandemic through an effective zakat program called the MSME Empowerment Program "Small Business Capital Assistance." 
Table 1 Respondent Data LAZISMU Pemalang

\begin{tabular}{ccl}
\hline No. & Staff Name & \multicolumn{1}{c}{ Position } \\
\hline 1. & AriFitriadi, ST, MT. & Secretary \\
2. & Imam Hadiyanto & $\begin{array}{l}\text { Executive Board (Program and Fundraising } \\
\text { Division) }\end{array}$ \\
3. & Suhendri & Executive Board (Finance Division) \\
\hline
\end{tabular}

Table 1 is the names of respondents from the amil zakat institution, including Mr. Fitriadi, ST, MT as Secretary of the Board of Executives, Mr. Imam Hadiyanto as the executive body in charge of the program and fundraising division, and Mr. Suhendri in charge of the financial division Three respondents were interviewed as primary sources by the author in order to obtain valid data for the research that the author will conduct. The Secretary is responsible for determining the form of zakat disbursement.

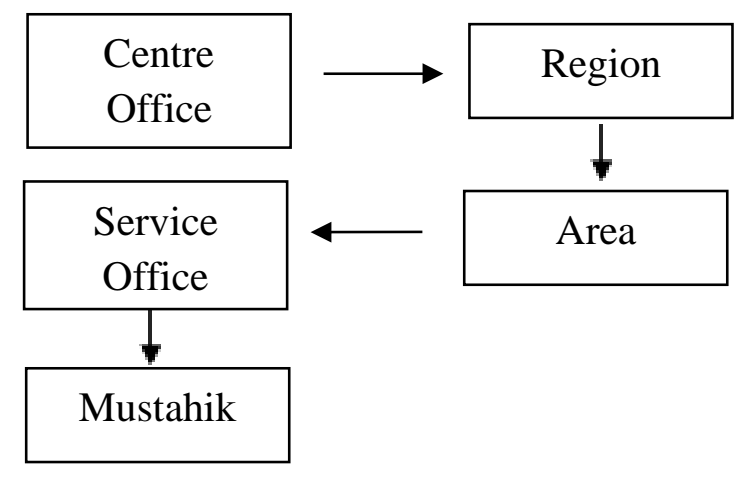

Figure 1 Business Capital Assistance Allocation Scheme

Figure 1 depicts the mechanism for allocating productive zakat in the form of capital assistance to mustahik who own a business. The region still divides the rations or portions obtained from each region, beginning with the central LAZISMU, which issued instructions to zakat institutions to carry out an effective program. LAZISMU Pemalang has received a share of 50 mustahik who will receive business capital assistance. Due to the financial constraints of LAZISMU Pemalang, business capital assistance is only available to 27 mustahiks.

Based on an interview with LAZISMU Pemalang staff, the following mechanisms for allocating productive zakat are implemented by LAZISMU Pemalang:

1. A Distribution Pattern of Small Business Capital Assistance

The distribution pattern implemented by LAZISMU Pemalang is creatively productive. Creative productivity here means providing assistance in the form of cash provided to be used as the additional business capital of small traders during the pandemic. Distribution conducted by LAZISMU Pemalang is through the provision of business capital through the service office in Pemalang Regency. The 
service office directly distributes the assistance mustahik who are entitled to obtain it.

2. Procedure for Recipients of Small Business Capital Assistance

Mustahik, who received business capital assistance during the pandemic, must follow the procedures used by, among others, LAZISMU Pemalang:

a) During the crew stage, LAZISMU Pemalang determines the part obtained from each service office through discussions with the governing body regarding the funds based on mustahik.

b) Each serviced office conducts a mustahik survey. The survey looked at mustahik houses, owned businesses, and income earned.

3. The mustahik chosen by the service office is a mustahik who already has a business.

The amount of assistance obtained by Mustahik is determined by a meeting with the governing body on the funds to be channeled and a discussion of Mustahik's business background. LAZISMU Pemalang owns this procedure, which ensures productive zakat distribution through business capital assistance in accordance with Sharia guidelines. The destitute dominate the distribution of productive zakat aid funds. They are a group of people who are unable to meet their basic needs due to a lack of capital. LAZISMU Pemalang determines asnaf based on which asnaf requires the most assistance and has previously conducted a survey related to the economic condition mustahik.

Following the service, the office provides data related to the business-owned mustahik, and the executive and governing bodies crosscheck whether the data adheres to the field conditions. If it is appropriate, Lazismu can decide who will receive business capital assistance from Mustahik. Because funds were scarce in the midst of the pandemic, the nominal amount given by LAZISMU Pemalang to mustahik could not be excessive. However, given the constraints, LAZISMU Pemalang tries to channel as much productive zakat funds as possible to help the mustahik economy affected by the pandemic. As a result, the nominal paid to mustahik varies, ranging from Rp 500,000 to Rp 1,000,000 per person.

4. Assistance Procedure

The distribution of business capital assistance is done in the form of cash, which is handed over to service offices in each sub-district. The service office went to each Mustahik's house to directly target the business capital assistance.

\section{In the Covid-19 pandemic, the Contribution of Productive Zakat to Economic Empowerment mustahik}

During the pandemic, LAZISMU Pemalang assisted mustahik infected with covid19. The action is carried out by distributing zakat in both a consumptive and productive manner. Productive zakat distribution is one of the options for ensuring that Mustahik can meet its needs indefinitely. Empowerment will be achieved if the needs are met. Empowerment means that with zakat funds on hand, LAZISMU Pemalang can channel its efforts into providing capital assistance so that those who 
receive it can develop their entrepreneurial potential, especially during the pandemic.

Table 1 Allocation of Small Business Capital Assistance to Mustahik

\begin{tabular}{cccc}
\hline $\begin{array}{c}\text { Service Office } \\
\text { Branch }\end{array}$ & Distribution & Business & Amount \\
\hline Belik & 2 Mustahik & $\begin{array}{c}\text { Food Online } \\
\text { Chicken Livestock } \\
\text { Brick Making } \\
\text { Moga }\end{array}$ & IDR 2,000,000 \\
& 6 Mustahik & Rp 3.000.000 \\
& & $\begin{array}{c}\text { Pineapple Garden } \\
\text { Business }\end{array}$ & \\
\hline
\end{tabular}

Source: LAZISMU Pemalang Documentation 2020

According to table 1, the allocation of productive zakat is given to mustahik, who previously had a business but was hampered by a lack of capital during the pandemic. This allocation policy is the result of zakat funds collected by LAZISMU Pemalang from two of the largest service office branches. Belik service office received $\mathrm{Rp} 2,000,000$ in capital assistance and was founded on two mustahik. In comparison, the Moga branch service office received $\mathrm{Rp} \mathrm{3,000,000} \mathrm{for} \mathrm{six}$ mustahik. This act is in accordance with Article 27 paragraphs 1 and 2 of Law No. 23 of 2011, which governs the management of zakat, where zakat is intended for people with a poor economy. (EZ and Maisyal 2020). Small business capital assistance is a gift intended to empower the community, and recipients are not required to repay the assistance. According to Mr. Ari from LAZISMU Pemalang, capital is expected to help Mustahik improve his standard of living and can even be used as a spirit to help him reach the level of muzakki.

Table 2 Productive Zakat as a Form of Empowerment Mustahik through Small Business Capital

\begin{tabular}{ccc}
\hline Mustahik & Business & Forms of Granting \\
\hline R & Chicken Livestock & Rp 1,000,000 \\
SP & Online Food Business & Rp 1,000,000 \\
SH & Snack Business & Rp 500,000 \\
N & Grocery Store Business & Rp 500,000 \\
M & Batako Making Business & Rp 500,000 \\
S & Pineapple Garden Business & Rp 500,000 \\
BAG & Batako Making Business & Rp 500,000 \\
\hline
\end{tabular}

Source: Data Processed 2020

Table 2 shows that the business capital assistance provided by LAZISMU Pemalang is in the form of cash used to increase Mustahik's business capital, rather than goods such as carts, tables, and so on. The distribution of business capital assistance by the Belik Service Office is as much as two people given to R and SP, amounting to Rp 1,000,000 per person. The fund can provide benefits in the form of a capital increase to sell, particularly for SP who have an online food business affected by covid-19, resulting in a decrease in income. Different conditions occur $\mathrm{R}$, the 
existence of business capital assistance can provide benefits to the economy, wherewith the help of capital can provide new business, because since the pandemic occurred R lost his job as a seller of mobile toys in school, then with the help provided LAZISMU Pemalang now $\mathrm{R}$ has a chicken livestock business. However, the profit has not been realized because the distribution assistance has only been in place for about two months.

Meanwhile, at the Moga Service Office, the funds based by LAZISMU Pemalang amounted to $\mathrm{Rp} 3,000,000$, which was distributed to six mustahik people with $\mathrm{Rp}$ 500,000 each. Mustahik comes from a poor family and does not have enough money to meet his needs, especially during the pandemic. M, a bricklayer, believes the pandemic has a negative impact on the economy. The demand for bricks has plummeted dramatically. Even basic necessities are still in short supply. According to interviews with five mustahik in the Moga subdistrict, the provision of business capital assistance could provide a slight boost to the capital owned by mustahik. $\mathrm{N}$ believed that the LAZISMU Pemalang aid was used to make banana chips that would be sold at his grocery store. S, a food seller of cassava base ingredients, is subjected to a variety of conditions. Because the pandemic makes his business difficult to buy, $S$ uses venture capital from LAZISMU Pemalang to try a new business, namely the pineapple business.

The interview results revealed that providing business capital is sufficient to alleviate the economic burden experienced during the pandemic by increasing business capital and meeting daily needs. However, as stated by $\mathrm{SH}$, the provision is still felt less by some mustahik, as the nominal given by LAZISMU Pemalang is regarded as a responsibility to increase capital. Nonetheless, on the other hand, the provision of business capital assistance has a reasonably good impact on the economy mustahik, where mustahik is able to improve the quality and ability of himself to continue running a business in the midst of the pandemic and is able to help mustahik escape the abyss of poverty.

The productive zakat distributed by LAZISMU Pemalang is classified in the creative utilization of productive zakat through these programs and procedures. The zakat funds allocated to mustahik are provided in the form of capital to encourage mustahik-owned businesses to continue operating in the midst of the pandemic. The grant is intended to ensure that the economy does not fall into the abyss of poverty. So that the ability and expertise owned by Mustahik in managing the business can develop as much as possible in the distribution of zakat funds allocated in an effective form, through the injection of funds provided by amil zakat (Romdhoni 2017). It is expected that the economy will be able to recover with the provision of capital assistance.

Using productive zakat for long-term activities like providing business capital assistance will create a tool to help the government combat poverty and unemployment. (Pratama, 2015). This goal is similar to LAZISMU Pemalang's goal 
of assisting mustahik in the midst of the pandemic, namely the hope that mustahik can avoid poverty and improve their standard of living.

\section{Evaluation of the Mechanisms and Contributions of Productive Zakat to Mustahik's Economy During the Pandemic}

LAZISMU Pemalang's allocation has followed Article 27 paragraphs 1 and 2 of Law No. 23 of 2011. When the needs mustahik have been met, productive zakat is distributed. (Judge 2016). This phenomenon can be seen in the pattern of productive zakat distribution, which is carried out by providing business capital assistance to mustahik who previously had a business. It is concluded from the mechanism of allocating productive zakat in the midst of the pandemic that to achieve maximum results in the distribution of productive zakat. Coaching and supervision are required, as is the case with the agency amil zakat, which monitors the implementation of an effective zakat program on a regular basis and conducts auditing field (Haidir 2019). However, LAZISMU Pemalang's limited human resources (HR) make supervision and coaching less effective, and external factors from the service office are focused on Lazismu Pemalang activities.

According to the findings of this study, some mustahik are in desperate need of coaching and supervision. Even the mustahik party invited LAZISMU Pemalang to visit the business owned by them to see firsthand the development of business capital assistance in the midst of the pandemic. With these obstacles, amil zakat institutions are concerned about optimizing coaching and supervision to mustahik.

Productive zakat in the form of money is more needed by the mustahik, particularly during a pandemic, so that the funds can be used to meet daily needs and increase business capital. They anticipate receiving business capital from LAZISMU Pemalang. During a pandemic like this, it has a massive impact on the economy, causing incomes to plummet dramatically. The reason for LAZISMU Pemalang's provision of capital is a lack of funds, so it has not provided assistance in the form of goods and finance mustahik business from the start.

The impact of the pandemic was felt not only by the upper class, but also by the lower class. Due to their low income, those who own small businesses face capital constraints. This condition has a negative impact on the community's economy, resulting in unemployment and poverty. Amil zakat strives to contribute by utilizing productive zakat to economically empower mustahik in the midst of the pandemic.

According to one viewpoint, utilizing zakat for the poor and indigent is more practical by delegating responsibility to mustahik to repay the loan known as Qardhul Hasan (Alim, 2015). Unlike LAZISMU Pemalang, which distributes business capital assistance in the form of grants and empowerment. The provision of business capital assistance is made without any obligation on the part of Mustahik to return capital assistance to aid in the recovery of the economy during a pandemic. It is the understanding of how to use zakat productively, where later 
Mustahik will be able to meet his life's needs continuously without relying solely on the institution of amil zakat. (Wahyuni, 2019).

LAZISMU Pemalang's contribution of productive Zakat has been made through productive zakat funds used as funds for the addition of business capital. The funds will be used for capital fundraising. Nonetheless, some mustahiks use some of the aid to meet their daily needs in order to survive the covid-19 pandemic.

The distribution of productive zakat in the form of business capital assistance is made in cash and given to traders who own small businesses for productive purposes. This type of distribution is in accordance with Law No. 23 of 2011, which governs the distribution of zakat and leads to effective forms. (B. R. Hakim, 2016). The grant of business capital assistance is used to purchase mustahik's business staples, allowing mustahik to earn an income in the midst of the pandemic, albeit a small one. Furthermore, productive zakat can be an alternative in assisting mustahik who have lost their livelihoods as a result of the pandemic, specifically through the provision of capital to start new businesses.

\section{CONCLUSION}

The mechanism of allocating productive zakat in the midst of the pandemic in empowering the mustahik economy is derived from LAZISMU's decision to create a program that can help overcome the impact of the pandemic through the use of creative, productive zakat distributed through each service office. The fund's limitations allocate productive zakat only once in the middle of the pandemic. Furthermore, due to a lack of Human Resources, the coaching and supervision provided by LAZISMU Pemalang have not been carried out optimally. However, LAZISMU Pemalang continues to do its best to distribute productive zakat to mustahik in need in the midst of the pandemic. According to the research, productive zakat contributes to mustahik economic empowerment during the pandemic, specifically through capital assistance to small traders. However, not all mustahik use all of the aid funds to develop the business; instead, they are used to meet daily needs. Mustahik in the pandemic requires fulfillment that has short-term benefits.

This study proposed that LAZISMU Pemalang and other zakat institutions provide a model of zakat distribution with Qardhul Hasan accounts in order to make mustahik have an obligation to manage as many business capital assistance funds as possible. Furthermore, supervision and construction are required to ensure that zakat is used for productive businesses. Furthermore, with the limited funds obtained, Mustahik can use it as motivation to manage funds and improve their standard of living. Because of the circumstances surrounding the covid-19 pandemic, this study has some limitations. Among other things, the research subjects studied are still unable to reach the entire population. Interviews with some mustahik were even conducted online by the author due to an increase in pandemic cases in mustahik areas where the author wanted to interview. Furthermore, the research object examined by the author is still limited to a single region. As a result, 
additional research is expected to add research objects to learn how one object compares to another.

\section{REFERENCES}

Alim, M. N. (2015). Utilization and Accounting of Zakat for Productive Purposes in Indonesia: A Review. Procedia - Social and Behavioral Sciences, 211, 232236. https://doi.org/10.1016/j.sbspro.2015.11.028

Badan Pusat Statistik. (2020). Persentase Penduduk Miskin Maret 2020 naik menjadi 9,78 persen. https://www.bps.go.id/pressrelease/2020/07/15/1744/persentase-pendudukmiskin-maret-2020-naik-menjadi-9-78-persen.html

Biro Humas Kemnaker. (2020). Pemerintah Antisipasi Penambahan Pengangguran di Masa Pandemi Covid-19. Kementerian Ketenagakerjaan Republik Indonesia. https://kemnaker.go.id/news/detail/pemerintahantisipasi-penambahan-pengangguran-di-masa-pandemi-covid-19

Dewan Syariah Lazis Muhammadiyah. (2011). Pedoman Zakat Praktis. Suara Muhammadiyah.

Efendi, M. (2017). Pengelolaan Zakat Produktif Berwawasan Kewirausahaan Sosial dalam Mengentaskan Kemiskinan di Indonesia [Management of Productive Zakat with Social Entrepreneurship Insight in Alleviating Poverty in Indonesia]. Al-Ahkam: Jurnal Ilmu Syari'ah Dan Hukum, 2(1), 21-38. https://doi.org/https://doi.org/10.22515/al-ahkam.v2i1.679

EZ, I., \& Maisyal, N. (2020). Pendayagunaan Zakat Untuk Penanggulangan Pandemi Covid-19 Perpektif Filsafat Hukum Islam [Utilization of Zakat for the Prevention of the Covid-19 Pandemic from the Perspective of Islamic Law Philosophy]. Al - Muamalat: Jurnal Hukum Dan Ekonomi Syariah, 5(1), 6. https://doi.org/https://doi.org/10.32505/muamalat.v5i1.1849

Fahri, Jalil, A., \& Kasnelly, S. (2020). Meningkatnya angka pengangguran ditengah pandemi (COVID-19) [Increasing unemployment rate amid pandemic (COVID-19)]. Al Mizan:Jurnal Ekonomi Syariah, 2(2), 45-60.

Faisal, A., \& Yuliani, I. (2018). Productive Zakat of Baznas Yogyakarta on the Growth of Micro Business. Shirkah: Journal of Economics and Business, 2(3). https://doi.org/10.22515/shirkah.v2i3.169

Fajrina, A. N., Putra, F. R., \& Sisillia, A. S. (2020). Optimalisasi Pengelolaan Zakat: Implementasi dan Implikasinya dalam Perekonomian [Optimizing Zakat Management: Its Implementation and Implications in the Economy]. Journal of Islamic Economics and Finance Studies, 1(1), 100. https://doi.org/10.47700/jiefes.v1i1.1918

Fauziyah, N. (2020). Wamenag: Berdayakan Zakat sebagai Solusi di Tengah Pandemi Covid-19.

Okemuslim. https://muslim.okezone.com/read/2020/07/20/614/2249142/wamenagberdayakan-zakat-sebagai-solusi-di-tengah-pandemi-covid-19?page $=1$

Fitri, M. (2017). Pengelolaan Zakat Produktif sebagai Instrumen Peningkatan Kesejahteraan Umat [Management of Productive Zakat as an Instrument for Improving the Welfare of the People]. Economica: Jurnal Ekonomi Islam, 8(1), 149-173. https://doi.org/10.21580/economica.2017.8.1.1830 
Haidir, M. S. (2019). Revitalisasi Pendistribusian Zakat Produktif Sebagai Upaya Pengentasan Kemiskinan di Era Modern [Revitalization of Productive Zakat Distribution as Efforts to Eradicate Poverty in the Modern Era]. Muqtasid: Jurnal Ekonomi Dan Perbankan Syariah, 10(1), 57. https://doi.org/10.18326/muqtasid.v10i1.57-68

Hakim, B. R. (2016). Analisis Terhadap Undang-Undang Nomor 23 Tahun 2011 Tentang Pengelolaan Zakat (Perspektif Hukum Islam) [Analysis of Law Number 23 Year 2011 Regarding Zakat Management (Islamic Law Perspective)]. Syariah Jurnal Hukum Dan Pemikiran, 15(2), 155-166. https://doi.org/10.18592/syariah.v15i2.552

Hakim, L., Alam, A., At-Thariq, M. M., Junaedi, D., \& Arsyad, M. R. (2021). Perbandingan Program Zakat Produktif antara BAZNAS dan LAZISMU Kota Surakarta. Al-Kharaj: Jurnal Ekonomi, Keuangan \& Bisnis Syariah, 4(1), 3346. https://doi.org/10.47467/alkharaj.v4i1.348

Hermawan, I. (2019). Metodologi Penelitian Pendidikan. Hidayatul Quran Kuningan.

IMF. (2020). Global Prospects and Policies. https://www.imf.org/en/Publications/WEO/Issues/2020/04/14/weo-april2020

Kurniawansyah, H., Amrullah, Salahuddin, Muslim, \& Nurhidayati, S. (2020). Konsep Kebijakan Strategis Dalam Menangani Eksternalitas Ekonomi Dari Covid - 19 Pada Masyarakat Rentan Di Indonesia [Strategic Policy Concepts in Dealing with Economic Externalities From Covid - 19 in Vulnerable Communities in Indonesia]. Indonesian Journal of Social Sciences and Humanities, $\quad$ Vol. 13 No.(2), 130-139. file:///C:/Users/User/Downloads/fvm939e.pdf

Leli, M. (2020). Urgensi Zakat Dalam Pemberdayaan Ekonomi di Masa Vandemi COVID Ditinjau Dari Prespektif Ekonomi Islam [The Urgency of Zakat in Economic Empowerment in the Vandemic Period of COVID Viewed from an Islamic Economic Perspective]. JURNAL AT-TASYRI'IY, 3(1), 8-23.

Nidityo, H. G., \& Laila, N. (2014). Zakat Produktif Untuk Meningkatkan Kinerja, Produksi, Motivasi dan Religiusitas Mustahiq [Productive Zakat to Increase Performance, Production, Motivation and Religiosity Mustahiq]. Jestt, 1(9), 661-673. https://doi.org/http://dx.doi.org/10.20473/vol1iss20149pp661-673

Pamungkas, I. B., Putranto, A. T., Pratama, A., Syah, A., \& Pamulang, U. (2020). Membangun Perekonomian di Lingkungan Masyarakat [Building the Economy in the Community]. Jurnal Dedikasi PKM Unpam, 1(2), 25-31. https://doi.org/https://doi.org/10.14203/jmi.v39i1.319

Pratama, Y. C. (2015). Peran Zakat Dalam Penanggulangan Kemiskinan (Studi Kasus : Program Zakat Produktif Pada Badan Amil Zakat Nasional) [The Role of Zakat in Poverty Alleviation (Case Study: Productive Zakat Program at the National Amil Zakat Board)]. The Journal of Tauhidinomics, 1(1), 93-104. https://doi.org/https://doi.org/10.15408/thd.v1i1.3327

Razak, S. H. A. (2020). Zakat and waqf as instrument of Islamic wealth in poverty alleviation and redistribution: Case of Malaysia. International Journal of Sociology and Social Policy, 40(3-4), 249-266. 
https://doi.org/10.1108/IJSSP-11-2018-0208

Rianto, A., Junaidi, \& Setyawan, A. (2016). Pelaksanaan Pasal 27 Undang-Undang No. 23 Tahun 2011 Mengenai Zakat Produktif di BAZNAS Kabupaten Karanganyar [Implementation of Article 27 of Law No. 23 Year 2011 Regarding Productive Zakat in BAZNAS Karanganyar Regency]. Yustisia, 5(2), 415-434. https://doi.org/https://doi.org/10.20961/yustisia.v5i2.8758

Romdhoni, A. H. (2017). Zakat Dalam Mendorong Pertumbuhan Ekonomi Dan Pengentasan Kemiskinan [Zakat in Encouraging Economic Growth and Poverty Alleviation]. Jurnal Ilmiah Ekonomi Islam, 3(1), 43. https://doi.org/10.29040/jiei.v3i01.98

Satuan Tugas Penangan COVID-19. (2020). Infografis COVID-19 (5 Oktober 2020). https://covid19.go.id/p/berita/infografis-covid-19-5-oktober-2020

Sugiyono. (2013). Metode Penelitian Kuantitatif Kualitatif dan $R \& D$ (Bandung). Alfabeta.

Supriyatno, H. (2020). Meningkatnya Angka Pengangguran dan Kemiskinan. Harian Bhirawa Online. https://www.harianbhirawa.co.id/meningkatnyaangka-pengangguran-dan-kemiskinan/

Utami, S., \& Lubis, I. (2014). Pengaruh Pendayagunaan Zakat Produktif Terhadap Pemberdayaan Mustahiq Di Kota Medan [The Effect of Productive Zakat Utilization on Empowerment of Mustahiq in Medan City]. Jurnal Ekonomi Dan Keuangan, 2(6), 353-366.

Wahyu, A. R. M., \& Anwar, W. A. (2020). Management of Zakat at BAZNAS Regency Sidrap During COVID- 19' s Pandemic. Jurnal Iqtisaduna, 1(1), 4.

Wahyuni, S. (2019). Pendayagunaan Zakat Produktif Dalam Meningkatkan Usaha

Masyarakat Melalui Program Bisa (Bunda Mandiri Sejahtera) Di Yatim Mandiri Surabaya [The Utilization of Productive Zakat in Improving Community Business through the Can (Bunda Mandiri Sejahtera) Progr. MAZAWA : Management of Zakat and Waqf Journal, 1(1), 28-42.

Widiastuti, T., \& Rosyidi, S. (2015). Model Pendayagunaan Zakat Produktif oleh Lembaga Zakat dalam Meningkatkan Pendapatan Mustahiq [Productive Zakat Utilization Model by Zakat Institutions in Increasing Mustahiq Income]. Jurnal Ekonomi Dan Bisnis Islam, 1(1), 89-102.

Worldometer. (2020). Coronavirus Update. Www.Worldometers.Info. https://www.worldometers.info/coronavirus/

Zalikha, S. (2016). Pendistribusian Zakat Produktif Dalam Perspektif Islam [Productive Zakat Distribution from an Islamic Perspective]. Jurnal Ilmiah Islam Futura, 15(2), 312. https://doi.org/10.22373/jiif.v15i2.547

Zhang, Y., Diao, X., Chen, K. Z., \& Dkk. (2020). Impact of COVID-19 on China's macroeconomy and agri-food system-an economy-widemultiplier model analysis. China Agricultural Economic Review, 12(3). https://doi.org/10.1108/caer-04-2020-0063 